\title{
Diurnal Course of the Main Heat Balance Components of a Marshy Meadow in the Lower Biebrza River Valley
}

\author{
Małgorzata Kleniewska $^{1 *}$, Dariusz Golaszewski ${ }^{1}$, Grzegorz Majewski ${ }^{1}$ \\ Sylwia Szporak-Wasilewska ${ }^{2}$, Katarzyna Rozbicka ${ }^{1}$, Tomasz Rozbicki ${ }^{1}$
}

${ }^{1}$ Division of Meteorology and Climatology, Department of Hydraulic Engineering, Warsaw University of Life Sciences, Nowoursynowska 166, 02-787 Warsaw, Poland ${ }^{2}$ Laboratory Water Centre, Warsaw University of Life Sciences, Poland

Received: 23 June 2014

Accepted: 13 October 2014

\begin{abstract}
Understanding the heat balance structure of the surface of a marshy meadow and the dynamics of its changes were the objectives of observations carried out in the valley of the Biebrza River. A simplified eddy covariance system allowed measurements of the density of four main energy balance components: latent (LE) and sensible (S) heat fluxes, soil heat flux $(\mathrm{G})$, and net radiation $(\mathrm{Rn})$.

The mean half-hourly values of the net radiation during our observations ranged from $-51 \mathrm{~W} \cdot \mathrm{m}^{-2}$ (nighttime) to $309 \mathrm{~W} \cdot \mathrm{m}^{-2}$ (daytime). The amount of available energy was used for evaporation in the first place - the latent heat flux assumed the highest values in the outgoing portion of the heat balance throughout the entire data series. Mean half-hourly values of latent heat varied between $-90 \mathrm{~W} \cdot \mathrm{m}^{-2}$ (at 3. p.m.) and $194 \mathrm{~W} \cdot \mathrm{m}^{-2}$ (at 1 a.m.). The values of sensible heat flux density were relatively low and ranged from $-16 \mathrm{~W} \cdot \mathrm{m}^{-2}$ to $96 \mathrm{~W} \cdot \mathrm{m}^{-2}$. During the day, the soil heat flux density ranged from $2 \mathrm{~W} \cdot \mathrm{m}^{-2}$ to $36 \mathrm{~W} \cdot \mathrm{m}^{-2}$, and the flux was most often directed from the active surface into the soil profile. At night, it assumed values within the range -24 to $-5 \mathrm{~W} \cdot \mathrm{m}^{-2}$.
\end{abstract}

Keywords: energy balance, wetlands, Biebrza River Valley, eddy covariance method, Bowen ratio method

\section{Introduction}

Wetlands cover about $6 \%$ of the land surface of the Earth [1]. They protect freshwater resources, biodiversity, and landscapes with exceptional natural properties, and are an essential component of the carbon cycle [2,3]. All these features make wetlands exceptionally important ecosystems for the existence of people and their preservation has motivated a number of international documents, such as the Ramsar Convention [4] and the Water Framework Directive [5]. In Poland, several national parks have been established to protect wetlands: Biebrza National Park,

*e-mail: malgorzata_kleniewska@sggw.pl
Narew National Park, Warta River Mouth National Park, and Polesie National Park, of which Biebrza is the largest, comprising the entire valley of the meandering Biebrza River and the country's largest system of peatlands. The unique, mosaic-like arrangement and zonality of wetland habitats are characteristic features of Biebrza park, which helped by extensive cultivation - have enabled conservation of rare plant and animal species. The protection of wetlands in the valley of the Biebrza consists in the maintenance of high levels of surface and ground water [6], which are indispensable for the provision of wetland soils with adequate moisture and preventing them from drying out and degrading. This requires appropriate water management methods [7]. With this kind of protective measure, it 
is necessary to carefully identify the heat balance structure of the ecosystems, correlated with the water balance through the evaporation process. An in-depth knowledge of the energy exchange in wetlands is important, as this determines radiation and temperature conditions, water transfer, development of vegetation and the productivity of the land [8]. Besides, understanding the heat balance structure is the basis for the determination of the evaporation rate because the available energy is the most important physical factor that limits the amount of evapotranspiration. Therefore, knowing the main components of heat balance allows us to appropriately assess the evaporation rate and this component of the heat and water balance has not yet been fully explored in the area of the Biebrza wetlands [9].

Understanding the heat balance structure of the surface of a marshy meadow and the dynamics of its changes were the objectives of observations carried out in the valley of the Biebrza, which consisted of the measurement of the density of four main heat fluxes. The eddy covariance method was used to measure the sensible heat flux, whereas the latent heat flux was determined using the Bowen ratio and the measured values of the sensible heat flux. The net radiation and the soil heat flux were measured as well.

\section{Experimental Procedures}

\section{Measuring Site}

The measurements were made in the area of Lawki

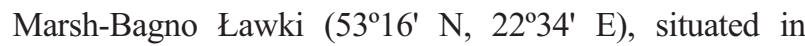
northeastern Poland, within the boundaries of Biebrza National Park, between 12 July 2010 and 8 August 2010. The area is a homogenous, flat meadow, typical of a river valley with slopes up to $0.3 \%$ and a width of approx. 13 $\mathrm{km}$. It is possibly the widest dense peatland complex in a lowland river valley in Poland [10]. The thickness of the peat deposits in the valley of the lower Biebrza reaches 1.5 $\mathrm{m}$, and exceeds to $2 \mathrm{~m}$ in places [11]. The habitat conditions in this part of the valley are largely shaped by underground water coming from the middle basin of the Biebrza, sourced from the eastern uplands [12], and by snowmelt water.

The climate of the Biebrza River basin is temperate transitional, with evident continental influences. The mean annual air temperature in the basin was $6.6^{\circ} \mathrm{C}$ in $1961-2000$, however, in individual years the mean values ranged from $4.8^{\circ} \mathrm{C}$ to $8.3^{\circ} \mathrm{C}$. The annual precipitation ranged from 536 $\mathrm{mm}$ to $610 \mathrm{~mm}$, and the mean annual wind speed was 3.8 $\mathrm{m} \cdot \mathrm{s}^{-1}[13]$. The basin features a medley of various climate conditions where different types of ground and vegetation exist, leading to both local and micro-scale variations in the climate. This diversity is mainly found in temperature and humidity conditions in the warm part of the year [14]. Lawki Marsh is an area predominated by Carex assemblages with an average height of approx. $70 \mathrm{~cm}$. The area is not cultivated, except for haying, which is carried out once a year from late summer until autumn. The heat balance structure was studied there before the haying season. The measuring site was located about $400 \mathrm{~m}$ from the so-called
Tsar's Road. The nearest thickets and tree groups (generally young birch) were about $400 \mathrm{~m}$ to the northeast from the location of the mast, and $450 \mathrm{~m}$ to the southeast. In the west, southwest and south of the mast was an open meadow enclosed by a wall of forest approx. $5 \mathrm{~km}$ from the south, and by the Biebrza River approx. $9 \mathrm{~km}$ from the west (Fig. 1).

\section{Methodology}

The studies consisted in taking appropriate measurements and determining the values of the main components of the heat balance for the active surface, using the following formula:

$$
\mathrm{Rn}+\mathrm{G}+\mathrm{LE}+\mathrm{S}=0
$$

...where:

$\mathrm{Rn}-$ net radiation $\left[\mathrm{W} \cdot \mathrm{m}^{-2}\right]$

$\mathrm{G}$ - soil heat flux density $\left[\mathrm{W} \cdot \mathrm{m}^{-2}\right]$

$\mathrm{S}-$ sensible heat flux density $\left[\mathrm{W} \cdot \mathrm{m}^{-2}\right]$

$\mathrm{LE}$ - latent heat flux density $\left[\mathrm{W} \cdot \mathrm{m}^{-2}\right]$

The sensible heat flux was measured using the eddy covariance method, described in detail in various sources [15-17]. Fluctuations of the three components of air mass movement and temperature were measured at $10 \mathrm{~Hz}$ using an ultrasonic anemometer (WindMaster, Gill Ins., UK) installed $3.5 \mathrm{~m}$ above the active surface (Fig. 2).

Latent heat flux (LE) was determined on the basis of the value of the sensible heat flux and the Bowen ratio, by means of the following formula [18]:

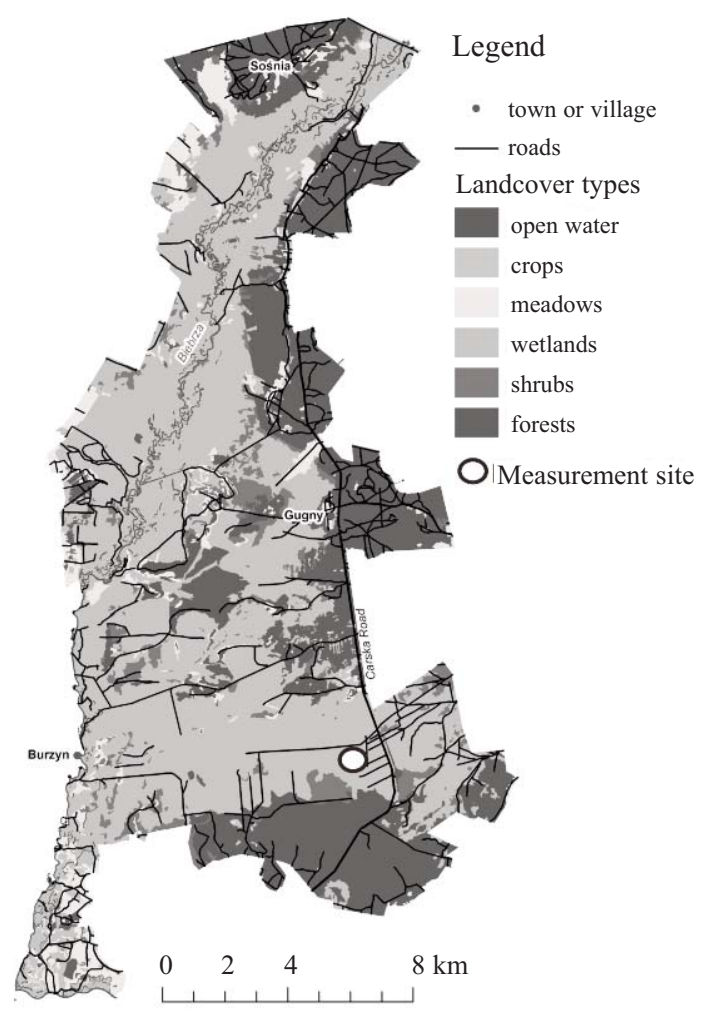

Fig. 1. Measurement site location. 


$$
\beta=\frac{S}{L E}=\gamma \cdot \frac{\Delta T}{\Delta e}
$$

...where:

S - sensible heat flux density

LE - latent heat flux density

$\gamma-$ psychrometric constant

$\Delta \mathrm{T}, \Delta \mathrm{e}$ - difference of the air temperature and pressure of the water vapour between two levels

The temperature and relative air humidity required for the calculation of $\beta$ were measured using thermohygrometers (HMP45A, Vaisala, FIN) installed at $0.5 \mathrm{~m}$ and $1.5 \mathrm{~m}$ above the active surface (Fig. 2).

Net radiation was measured using a net radiometer (NRLite, Kipp\&Zonen, NL) placed $1.5 \mathrm{~m}$ above the active surface (Fig. 2).

In order to measure the soil heat flux density, four heat flux plates (HFP01, Hukseflux, NL) were placed at a depth of $1 \mathrm{~cm}$ in the corners of a 1 metre square (Fig. 2).

Net radiation, density of soil heat flux, and temperature and relative humidity of the air were recorded as average 1minute values. For this purpose, a datalogger was used (CR1000, Campbell, UK), and the whole system was powered by a car battery. The measurement set up was inspected every 12 hours.

\section{Data Quality}

The applied measurement methods, and the eddy covariance method in particular, require verification of obtained data and evaluation of the reliability of results. There are a number of available tests described in the literature, but for the same test different authors have sometimes used different rejection threshold values. For the purpose of this paper, then, the following tests were carried out:

a. Conditions of turbulent exchange were examined by calculating and analyzing so-called friction velocity $\left(u^{*}\right)$. The threshold value of friction velocity was established $\left(\mathrm{u}^{*}=0.20 \mathrm{~ms}^{-1}\right)$, below which there is not enough mixing in the atmosphere to successfully apply the eddy covariance method [15]. b. Stationarity values of the sensible heat flux were also examined by determination of the covariance of the vertical components of wind velocity and air temperature every five minutes in each 30-minute period. The flux was considered stationary if the average value of the five-minute covariance within the 30-minute period did not diverge more than $30 \%$ from the covariance of the whole 30-minute period [19]. The stationarity assumes that for statistical parameters, e.g. mean values, variation of studied time series is stable at time of analysis.

c. Having performed the quality analysis on the data, the coordinate system was rotated. For the 30-minute averaging periods a double rotation was used: around the vertical axis $z$, which gave $\bar{v}=0$, and around the $y$ axis, which yielded $\bar{w}=0$ [20]. Rotation of the coordinate system eliminates situations in which measurements are conducted with non-zero of the mean vertical wind components (such a situation is possible when a sensor is in a non-vertical position).

d. The final evaluation of the quality of the data involved flagging individual 30-minute values of the sensible heat flux with numbers from 1 to 9 , according to the test results [21]. Data marked with Flag 1 were considered the most reliable, whereas the data marked with Flag 9 were rejected from the data set.

The data used to determine the Bowen ratio were also quality tested. Any instances of temperature differences or relative humidity indications between two levels that were smaller or equal to the accuracy of the measurement were excluded from the data series, according to the procedure provided by Perez et al. [22]. We excluded from the data series interval of $\beta$ values expressed by the equation:

$$
-1-|s|<\beta<-1+|s|
$$

...where:

$\varepsilon=\frac{\delta \Delta e-\gamma \Delta T}{\Delta e}$

$\delta \Delta \mathrm{e}, \delta \Delta \mathrm{T}-$ resolution limits for the water vapour and air temperature gradients

$\gamma-$ psychrometric constant.

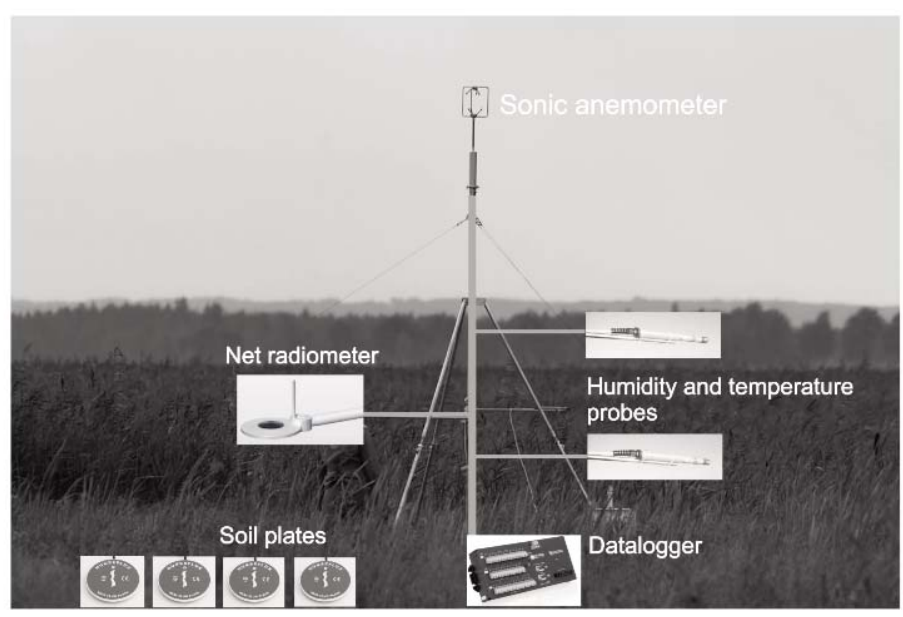

Fig. 2. Heat balance components measurement system. 


\section{Results and Discussion}

The weather at the time of the observations was scorching hot and stormy with the occasional arrival of cooler air masses. The 30-minute mean values of air temperature during the measurements ranged from 10.3 to $34.5^{\circ} \mathrm{C}$, and the diurnal mean values from 15 to $26^{\circ} \mathrm{C}$. In the course of the measuring session some precipitation occurred, mainly in the form of passing convectional rainfall.

The results of analysis of the diurnal course of the main heat balance components were presented for a sunny day, a cloudy day, and for days when a substantial change in the weather was observed.

The results of the measurements and calculations presented in this paper are the first of their kind for the Biebrza wetlands. As such, there are no published sources that may serve as references.

Our sign convention is different for Rn (positive when flux is directed towards the active surface) and different for LE, $\mathrm{S}$, and $\mathrm{G}$ (positive when flux is directed from the active surface).

The value and properties of the heat balance are mainly determined by the amount of energy available in the environment, which in turn results from the net radiation $(\mathrm{Rn})$ of the given surface. The diurnal course of net radiation for the measurement period is shown in Fig. 3 and mean halfhourly values ranged from $-35 \mathrm{~W} \cdot \mathrm{m}^{-2}$ (at 9:30 p.m.) to 460 $\mathrm{W} \cdot \mathrm{m}^{-2}$ (at noon) During the observations, the most frequent pattern of Rn values was the typical one, i.e. where the net radiation was positive at day and negative at night. The only exception was recorded on 13 July 2010 (Fig. 4). On that day, the net radiation followed a standard pattern for a cloudless day, with $\mathrm{Rn}$ values increasing to $616 \mathrm{~W} \cdot \mathrm{m}^{-2}$ at $11 \mathrm{a} . \mathrm{m}$. However, storm clouds developed later on and the ensuing rainfall resulted in a dramatic decrease of the 30-minute values of $\mathrm{Rn}$, to as much as $-94 \mathrm{~W} \cdot \mathrm{m}^{-2}$ at $2 \mathrm{p} . \mathrm{m}$.

Daytime (averaged between sunrise to sunset) net radiation in the period of observations ranged from 101 to 309 $\mathrm{W} \cdot \mathrm{m}^{-2}$, whereas the nighttime values fell within a range of -51 to $-15 \mathrm{~W} \cdot \mathrm{m}^{-2}$, with maximum 30 -minute values reaching over $600 \mathrm{~W} \cdot \mathrm{m}^{-2}$ in sunny weather (Figs. 4 and 5). On a cloudy day, the maximum $\mathrm{Rn}$ value was only $330 \mathrm{~W} \cdot \mathrm{m}^{-2}$ (Fig. 6).

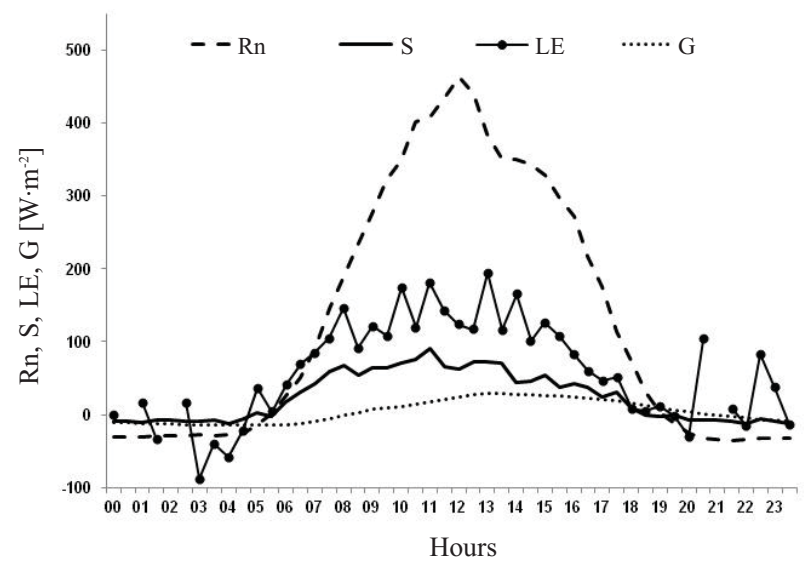

Fig. 3. Mean daily course of heat balance components from 12 July 2010 to 8 August 2010.
In the diurnal course of the net radiation, distinctive moments where the sign of the $\mathrm{Rn}$ flux change were also observed. These did not correspond to the timing of the sunrise or the sunset. A morning change of Rn values from negative to positive was observed about 1-1.5 hours after sunrise, and an evening transition of positive $\mathrm{Rn}$ values to 0 occurred about 1-1.5 hours before sunset, which must be the result of the thermal inertia of the active surface concerned. This is a typical characteristic, resulting from specific thermal capacity of the analyzed ecosystem (other than zero).

The amount of available energy, according to the value of the radiation balance, was used for evaporation in the first place - the latent flux (LE) always demonstrated the biggest values in the outgoing part of the balance, throughout the whole 4-week-long data series. This is connected with the availability of water within the analyzed area. At the time of the observations, the soil was saturated and a thin layer of water remained on the surface of the meadow after rainfall. Except for a day with rainfall, the diurnal course of latent heat flux was nearly a mirror image of the course of the radiation balance (Figs. 5 and 6). Mean half-hourly values of latent heat from 192 to $220 \mathrm{DOY}$ (Fig. 3) ranged from $-90 \mathrm{~W} \cdot \mathrm{m}^{-2}$ (at $3 \mathrm{a} . \mathrm{m}$.) to $194 \mathrm{~W} \cdot \mathrm{m}^{-2}$ (at $1 \mathrm{p} . \mathrm{m}$.). Magnitudes of LE mentioned above are lower than values observed by other authors on wetlands. Lafleur [23] recorded for sedgedominated wetlands midday LE ranging from 210 to 400 $\mathrm{W} \cdot \mathrm{m}^{-2}$, while Smid [24] reported midday LE ranging from 400 to $500 \mathrm{~W} \cdot \mathrm{m}^{-2}$ for reed swamp. For other areas in Poland, Michailović et al. [25] reported maximum hourly values of latent heat fluxes about $220 \mathrm{~W} \cdot \mathrm{m}^{-2}$ (apple orchard), 250 $\mathrm{W} \cdot \mathrm{m}^{-2}$ (rapeseed), and $300 \mathrm{~W} \cdot \mathrm{m}^{-2}$ (spring wheat).

Since most of the available energy in Ławki Marsh was used for evaporation, the values of the sensible heat flux density (S) were relatively low (Figs. 4 to 6). The sensible heat flux results from the process of heat exchange between the active surface and the atmosphere (warming up or cooling down of the air adjacent to the given surface). The diurnal course of the sensible heat flux followed a similar pattern to the course of the latent heat flux. The absolute values of the S flux were substantially lower at night (by an order of magnitude) than at day, which might be the effect of lesser turbulence (i.e. a less intense mixing of air).

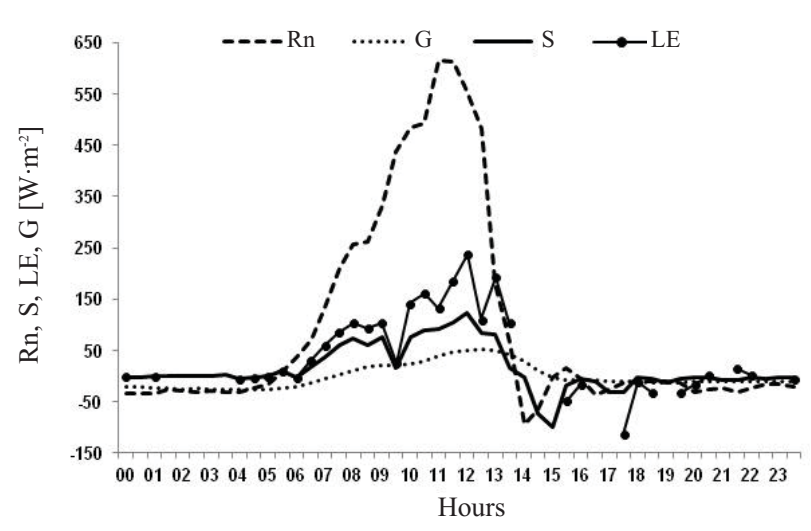

Fig. 4. Daily course of heat balance components on 13 July 2010 in Ławki Marsh. 
The daytime (averaged from sunrise to sunset) of the sensible heat flux during the observations ranging from $8 \mathrm{~W} \cdot \mathrm{m}^{-2}$ to $96 \mathrm{~W} \cdot \mathrm{m}^{-2}$ to, whereas their night values fell within the range of $-16 \mathrm{~W} \cdot \mathrm{m}^{-2}$ to $-1 \mathrm{~W} \cdot \mathrm{m}^{-2}$. Similar magnitude of sensible heat flux, ranging from $0-95 \mathrm{~W} \cdot \mathrm{m}^{-2}$ reported Smid [24], while Burba [26] recorded values from $0-40 \mathrm{~W} \cdot \mathrm{m}^{-2}$ during the day for marsh dominated by Phragmites Australis ( $40 \%$ of area), Scirpus acutus (30\%), and by open water area $(30 \%)$. The magnitude of LE in his study was larger, however.

For other types of vegetation cover in Poland, recorded hourly values of sensible heat fluxes were about $60 \mathrm{~W} \cdot \mathrm{m}^{-2}$ (spring wheat), $130 \mathrm{~W} \cdot \mathrm{m}^{-2}$ (apple orchard), and $170 \mathrm{~W} \cdot \mathrm{m}^{-2}$ (rapeseed) [25].

Another component of the heat balance is the soil heat flux (G). Its density and flow direction is related to the warming or cooling of the soil profile. During the day, the average density of the soil heat flux ranged from $2 \mathrm{~W} \cdot \mathrm{m}^{-2}$ to $36 \mathrm{~W} \cdot \mathrm{m}^{-2}$ (half-hourly peak of about $90 \mathrm{~W} \cdot \mathrm{m}^{-2}$ ), with the flux most often directed from the active surface into the soil profile. During the measuring session, only three days were observed where the heat flux was directed toward the active surface, and the diurnal values of the soil heat did not then exceed $-2 \mathrm{~W} \cdot \mathrm{m}^{-2}$. This change of the flow direction was connected with the transition of a cold front, at the time of which the 30-minute values of maximum air temperature dropped from $34^{\circ} \mathrm{C}$ to $20^{\circ} \mathrm{C}$.

The soil heat flux at night assumed values from -24 to $-5 \mathrm{~W} \cdot \mathrm{m}^{-2}$. There was only one case where the flux was directed into the soil at night, and its mean value for that period amounted to $5 \mathrm{~W} \cdot \mathrm{m}^{-2}$. The measured values are lower to those reported by Smid for reed swamp [24]. He recorded daytime peak of about $200 \mathrm{~W} \cdot \mathrm{m}^{-2}$ and night values from -100 to $-50 \mathrm{~W} \cdot \mathrm{m}^{-2}$. Burba [26] measured nighttime soil heat values between -70 and $-20 \mathrm{~W} \cdot \mathrm{m}^{-2}$.

In the diurnal course of soil heat flux, a shift of the moment of occurrence of the absolute maximum value was observed in relation to the maximum value of the net radiation. This shift ranged from 1.5 to 4 hours and resulted from thermal inertia of the system, as the thermal capacity of a highly-saturated soil profile slows down the process of ground warming, and thus leads to a delay of the moment of occurrence of the maximum 24-hour value of the soil heat flux, in comparison to the value of the net radiation. In previous, standard meteorological observations conducted on a number of different active surfaces in the Valley of the Biebrza River [14], the diurnal courses of soil temperature at different depths were measured, among other things. It was found that in the case of constantly paludified peat soil (i.e. in similar conditions to those of the Ławki Marsh), the maximum value of soil temperature occurred at about 5 p.m., or 2-2.5 hours later than in the case of moist clay soil.

\section{Conclusions}

The value and characteristics of the heat balance are mainly determined by the amount of energy available in the environment, which results from the net radiation $(\mathrm{Rn})$ of the analyzed surface. During the measuring session, a typical course of Rn values was most often observed, in which the net radiation assumes positive values during the day, and negative values at night. The diurnal mean values (from sunrise to sunset) of the net radiation during our observation ranged from 101 to $309 \mathrm{~W} \cdot \mathrm{m}^{-2}$, whereas at night these fell within a range from -51 to $-15 \mathrm{~W} \cdot \mathrm{m}^{-2}$. The amount of available energy resulting from the net radiation, was used for evaporation in the first place - the latent heat flux (LE) assumed the highest values in the outgoing portion of the heat balance throughout the entire 4-week data series.

Except for days when precipitation occurred, the diurnal courses of both the sensible and latent heat fluxes were nearly identical with the course of the radiation balance.

In Ławki Marsh, most available energy was used in the water-phase transition process, and so the values of sensible heat flux density (S) were relatively low. The mean diurnal values of sensible heat flux at the time of observation ranged from $8 \mathrm{~W} \cdot \mathrm{m}^{-2}$ to $96 \mathrm{~W} \cdot \mathrm{m}^{-2}$, whereas their nighttime counterparts ranged from -16 to $-1 \mathrm{~W} \cdot \mathrm{m}^{-2}$.

Another measured component of the heat balance was soil heat flux $(\mathrm{G})$. Its density and flow direction is connected with the warming up and cooling down of the soil profile. During the day, soil heat flux density ranged from 2 to $36 \mathrm{~W} \cdot \mathrm{m}^{-2}$, and the flux was most often directed from the active surface into the soil profile. At night, it assumed values within a ranging of -24 to $-5 \mathrm{~W} \cdot \mathrm{m}^{-2}$.

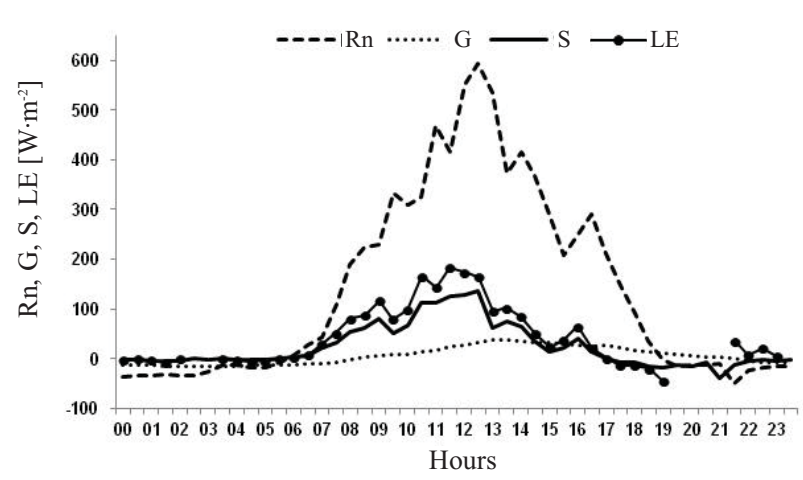

Fig. 5. Daily course of heat balance components on 6 August 2010 in Ławki Marsh.

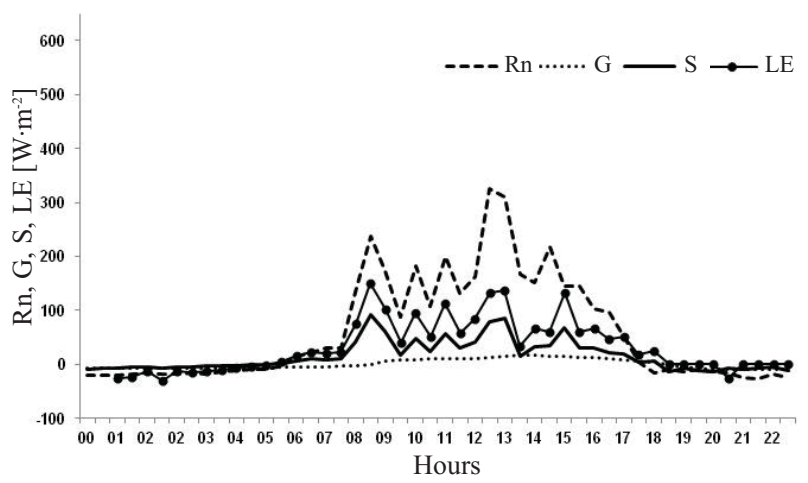

Fig. 6. Daily course of heat balance components on 27 July 2010 in Ławki Marsh. 


\section{Acknowledgements}

The present scientific work was financed from the state budget resources for the years 2008-2010.

\section{References}

1. ACREMAN M. C., FISHER J., MOULD D. J., STRATFORD C. J., MOUNTFORD J. O. Hydrological science and wetland restoration: some case studies from Europe, Hydro. Earth Sys. Sci., 11, (1), 158, 2007.

2. NATURE Reports Climate Change, 3, Macmillan Publishers, www.nature.com/reports/climatechange, December 2009.

3. CHOJNICKI B., MICHALAK M., KONIECZNA N., OLEJNIK J. Sedge Community (Caricetum elatae) Carbon Dioxide Exchange Sesonal Parameters in a Wetland. Pol. J. Environ. Stud., 21, (3), 579, 2012.

4. The Ramsar Convention Manual, $6^{\text {th }}$ edition (http://www.ramsar.org/pdf/lib/manual6-2013-e.pdf)

5. Directive 2000/60/EC of the European Parliament and of the Council (OJ L 327, 22.12.2000, p.1)

6. MIODUSZEWSKI W., OKRUSZKO T. Protection of natural wetlands-the examples of conflicts. J. Water Land Dev., 16, 35, 2012.

7. KARDEL I., MIROSŁAW-ŚWIĄTEK D., CHORMANSKI J., OKRUSZKO T., WASSEN M. Water management decision support system for Biebrza National Park, Env. Protect. Eng., 35, (2), 173, 2009.

8. BURBA G.G., VERMA S.B., KIM J. Surface energy fluxes of Phragmites australis in a praire wetland, Agr. For. Met., 94, 31, 1999.

9. BYCZKOWSKI A., FAL B. Waters of the Biebrza Valley, [In]: The Biebrza Valley and the Biebrza National Park. Biological monograph, Ed. H. Banaszuk, Ekonomia i Środowisko, Białystok, pp. 113-183, 2004, [In Polish].

10. DEMBEK W. Selected aspects of diversification of peatlands in the Young and old glacial landscapes of eastern Poland, Rozpr. Habil. Falenty, Wyd. IMUZ, 2000 [In Polish].

11. DEMBEK W., OŚWIT J., RYCHARSKI M. Peatlands and peats in the Biebrza Valley, in: Nature of the Biebrza National Park, ed. A. Dyrcz., Werpachowski C., Osowiec Twierdza, 33-58, 2005 [In Polish].

12. OKRUSZKO T., WASILEWICZ M., DEMBEK W., RYCHARSKI M., MATUSZKIEWICZ A. Changes of water conditions, plant cover and soils on bagno ławki in the
Biebrza River lower basin, Water Environment Rural Areas, Problems of Agricultural Egineering, 3, (1), 107, 2003 [In Polish].

13. GÓRNIAK A. Climate and surface water thermal conditions at the Biebrza River Valley, [In]: The Biebrza Valley and the Biebrza National Park. Biological monograph, ed. H. Banaszuk, Ekonomia i Środowisko, Białystok, pp. 113-183, 2004 [In Polish].

14. KOSSOWSKA-CEZAK U. The climate of the Biebrza icemarginal Valley. Pol. Ecol. Stud. 10, (3-4), 1984.

15. AUBINET M., VESALA T., PAPALE D. Eddy Covariance, A Practical Guide to Measurement and Data Analysis, Springer Atmospheric Sciences, 2012.

16. CHOJNICKI B.H., URBANIAK M., JÓZEFCZYK D., AUGUSTIN J., OLEJNIK J. Measurements of gas and heat fluxes at Rzecin wetland (Conference Paper), Proceedings of the International Conference W3M "Wetlands: Modelling, Monitoring, Management," 125-131, 2007.

17. FORTUNIAK K., PAWLAK W., SIEDLECKI M. Integral turbulence statistics over a Central European City Centre, Boundary - Layer Meteorol., 146, (2), 257, 2013.

18. BOWEN I. S. The ratio of heat losses by conduction and evaporation from any water surface. Physical Review, 27, 1926.

19. LEE X. (Ed.). Handbook of Micrometeorology, A Guide for Surface Flux Measurement and Analysis, Kluwer Academic Publishers. The Netherlands, 19, 2004.

20. AURELA M. Carbon dioxide exchange in subarctic ecosystems measured by a micrometeorological technique. Finnish Meteorological Institute Contributions, 51, 2005.

21. FOKEN T., GÖCKEDE M., MAUDER M., MAHRT L., AMIRO B.D., MUNGER J.W. Post-field data quality control, [In]: LEE X., MASSMAN W., LAW B., (Eds.), Handbook of Micrometeorology: A guide for surface flux measurement and analysis, Kluwer Acad. Publ., Dordrecht, 181, 2004.

22. PEREZ P.J., CASTELlVI F., IBANEZ M., ROSELL J.I. Assessment of reliability of Bowen ratio method for partitioning fluxes, Agr. For. Met., 97, 141, 1999.

23. LAFLEUR P.M. Evapotranspiration from sedge - dominated wetland surface, Aquat. Bot. 37, 341, 1990.

24. SMID P. Evaporation from reedswamp. J. Ecol., 63, 299, 1975.

25. MICHAILOVIĆ D.T., LALIĆ B., LEŚNY J., OLEJNIK J. Modeling surface fluxes over a sparse vegetation, Arch. Biol. Sci., 64, (4), 1533, 2012.

26. BURBA G.G., VERMA S.B., KIM J. Surface energy fluxes of Phragmites australis in a prairie wetland. Agric. For. Met. 1999. 